\title{
ANALISIS PENGARUH INFLASI, JUMLAH UANG BEREDAR DAN PRODUK DOMESTIK BRUTO TERHADAP RETURN ON ASSET (ROA) BANK SYARIAH DI INDONESIA
}

\author{
Ibnu Seyna Riyanto \\ ibnuseyna@gmail.com \\ Universitas Ahmad Dahlan \\ Salamatun Asakdiyah \\ salamatun_2009@yahoo.com \\ Universitas Ahmad Dahlan
}

\begin{abstract}
ABSTRAK
This study aims to explain the analysis of the influence of inflation, amount of money supply and gross domestic product to return on assets (ROA) Islamic Banks in Indonesia for the period 2010-2014. Macroeconomic variables used in this research are inflation, the amount of money supply and gross domestic product. Indicators used to assess performance Islamic Bank finance in this study is Return On Assets (ROA). This research uses documentation method with secondary data obtained from the Bank Indonesia website, the Central Statistics Agency and the respective Bank's website. The sampling technique used in this study using a purposive sampling method, so the number of samples is used in this study amounted to 7 Islamic banks in Indonesia. Technique data analysis uses multiple linear regression analysis, classical assumption test and significance test. The results showed, partial inflation was not significant effect on Return On Assets (ROA). The money supply partially negative and significant effect on Return On Assets (ROA). Gross Domestic Product has a positive and significant effect on Return On Assets (ROA). Whereas simultaneously shows inflation, amount money supply and gross domestic product have a significant effect on Return On Assets (ROA).
\end{abstract}

Keywords: Inflation; Amount of Money Supply; Gross Domestic Product; Return On Asset (ROA).

\section{PENDAHULUAN}

Krisis moneter yang terjadi pada tahun 1998 telah membuat beberapa bank konvensional dilikuidasi karena tidak mampu melaksanakan kewajibannya terhadap nasabah sebagai akibat dari kebijakan bunga yang tinggi yang ditetapkan pemerintah selama krisis berlangsung. Kebijakan tersebut diambil pemerintah sebagai tindakan untuk menekan jumlah uang beredar di masyarakat untuk menekan laju inflasi yang semakin melambung. Sebagai perbankan yang tidak menganut sistem bunga menyebabkan Bank Syariah tidak mengalami pergerakan negatif. Bank syariah tidak memiliki kewajiban untuk membayar bunga simpanan kepada para nasabahnya. Bank syariah hanya membayar bagi hasil kepada nasabahnya sesuai dengan keuntungan yang diperoleh bank dari hasil investasi yang dilakukannya. Jika pada tahun 1998 hanya ada satu Bank Umum Syariah, maka pada tahun 2015 (berdasarkan data Statistik Perbankan Syariah yang dipublikasikan oleh Bank Indonesia) jumlah Bank Syariah telah mencapai 36 unit yang terdiri atas 11 Bank Umum Syariah dan 25 Unit Usaha Syariah. 
Bank syariah sebagai lembaga perantara keuangan diharapkan dapat menunjukkan kinerja yang lebih baik dibandingkan bank berbasis bunga. Salah satu indikator untuk menilai kinerja keuangan bank adalah melihat tingkat profitabilitasnya serta tingkat efisiensinya. Ukuran proftabilitas yang digunakan adalah Return On Asset (ROA). Return on Asset (ROA) memfokuskan kemampuan perusahaan untuk memperoleh earning dalam operasi perusahaan. Semakin besar Return On Asset (ROA) menunjukan kinerja keuangan yang semakin baik, karena tingkat kembalian (return) semakin besar (Husnan, 1992).

Bank dalam kegiatan operasionalnya tidak lepas dari pengaruh kondisi perekonomian. Dalam penelitian ini menggunakan analisis dari luar perusahaan yaitu dengan menggunakan analisis lingkungan makro ekonomi. Variabel makro ekonomi yang digunakan adalah Inflasi, Jumlah Uang Beredar dan Produk Domestik Bruto (GDP) dimana ketiga faktor ini merupakan dampak dari krisis finansial global tahun 2008, dan sangat mempengaruhi kondisi perekonomian Indonesia.

Oktavia (2009) inflasi yang tinggi dapat menyebabkan menurunnya profitabilitas suatu perusahaan. Suardani (2009) dan Setiadi (2010) juga mengatakan bahwa inflasi berpengaruh signifikan terhadap Return On Asset (ROA). Menurut Rivai (2007) meningkatnya jumlah uang beredar di masyarakat dapat menunjang kegiatan perekonomian masyarakat, apabila kegiatan usaha masyarakat meningkat maka pendapatan masyarakat juga akan meningkat sehingga kemampuan masyarakat untuk menabung di bank juga akan meningkat. Menurut Khizer (2009) dalam Sahara (2013) tingkat pendapatan yang diukur dengan Produk Domestik Bruto (GDP) akan mempengaruhi pola saving dari seseorang, semakin besar GDP maka profitabilitas bank juga akan meningkat.

Tujuan dari penelitian ini di antaranya: 1) untuk mengetahui pengaruh Inflasi secara parsial terhadap Return On Asset (ROA) Bank Syariah di Indonesia periode 2010-2014, 2) untuk mengetahui pengaruh Jumlah Uang Beredar secara parsial terhadap Return On Asset (ROA) Bank Syariah di Indonesia periode 20102014, 3) untuk mengetahui pengaruh Produk Domestik Bruto (GDP) secara parsial terhadap Return On Asset (ROA) Bank Syariah di Indonesia periode 20102014 dan 4) untuk mengetahui pengaruh Inflasi, Jumlah Uang Beredar dan Produk Domestik Bruto (GDP) secara simultan terhadap Return On Asset (ROA) Bank Syariah di Indonesia periode 2010-2014.

\section{REVIEW LITERATUR DAN HIPOTESIS}

\section{Landasan Teori}

1. Bank Syariah

Bank Syariah adalah lembaga keuangan yang usaha pokoknya memberikan pembiayaan dan jasa-jasa lainnya dalam lalu lintas pembayaran serta peredaran uang yang pengoperasiannya disesuaikan dengan prinsip syariat Islam (Muhammad, 2005).

\section{Return On Asset (ROA)}

Return On Asset (ROA) adalah salah satu rasio yang digolongkan dalam Rasio Profitabilitas. Rasio Profitabilitas adalah sekelompok rasio yang menunjukan kombinasi dari pengaruh likuiditas, manajemen aset dan utang pada hasil operasi (Houston, 2004).

3. Inflasi

Boediono (1987) dikutip dalam Julianti (2013) mengemukakan bahwa inflasi adalah kecenderungan dari harga-harga untuk naik secara umum 
dan terus-menerus dalam jangka waktu yang lama.

\section{Jumlah Uang Beredar}

Boediono (2008) jumlah uang beredar dalam pengertiannya dapat dipahami dalam arti luas (M2) dan arti sempit (M1). Dalam arti sempit uang beredar adalah seluruh uang kartal dan uang giral yang tersedia untuk digunakan masyarakat. Sedangkan dalam arti luas uang beredar adalah penjumlahan M1 dengan deposito berjangka dan saldo tabungan milik masyarakat pada bank.

\section{Produk Domestik Bruto (GDP)}

Produk Domestik Bruto (Gross Domestic Product/GDP) adalah seluruh barang dan jasa yang dihasilkan seluruh warga masyarakat (termasuk warga negara asing) suatu negara dalam periode tertentu, biasanya dalam kurun waktu satu tahun (Soebagyo, 2013).

\section{Penelitian Terdahulu}

Sahara (2013), meneliti tentang Analisis Pengaruh Inflasi, Suku Bunga Bank Indonesia (BI Rate) dan Produk Domestik Bruto (GDP) terhadap Return On Asset (ROA) Bank Syariah di Indonesia. Dengan periode pengamatan selama 3 tahun yaitu dari tahun 2008 sampai tahun 2010. Menunjukkan bahwa Produk Domestik Bruto (GDP) berpengaruh positif terhadap Return On Asset (ROA) Bank Syariah di Indonesia.

Dwijayanthy (2010), meneliti tentang Analisis Pengaruh Inflasi, BI Rate dan Nilai Tukar Mata Uang terhadap Profitabilitas Bank Syariah di Indonesia. Dengan periode pengamatan selama 5 tahun yaitu dari tahun 2003 sampai tahun 2007. Menunjukkan bahwa Inflasi berpengaruh negatif terhadap profitabilitas Bank Syariah di Indonesia.

\section{Hipotesis}

H1: Inflasi secara parsial berpengaruh negatif terhadap Return On Asset (ROA) Bank Syariah di Indonesia.

H2: Jumlah Uang Beredar secara parsial berpengaruh positif terhadap Return On Asset (ROA) Bank Syariah di Indonesia.

H3: Produk Domestik Bruto (GDP) secara parsial berpengaruh positif terhadap Return On Asset (ROA) Bank Syariah di Indonesia.

H4: Inflasi, Jumlah Uang Beredar dan Produk Domestik Bruto (GDP) secara simultan berpengaruh signifikan terhadap Return On Asset (ROA) Bank Syariah di Indonesia.

\section{METODE PENELITIAN}

\section{Populasi dan Sampel}

Populasi adalah wilayah generalisasi yang terdiri dari obyek atau subyek yang mempunyai kualitas dan karakteristik tertentu yang ditetapkan oleh peneliti untuk dipelajari dan kemudian ditarik kesimpulan (Sugiyono, 2007). Dalam penelitian ini populasi yang diambil sebagai bahan dalam penelitian ini adalah Bank Umum Syariah yang ada di Indonesia. Jumlah Bank Umum Syariah yang ada di Indonesia saat ini berjumlah 11 unit.

Sampel adalah sub kelompok atau sebagian dari populasi. Sampel terdiri dari angggota yang dipilih dari populasi (Sekaran, 2006). Sampel dalam penelitian ini diambil berdasarkan metode purposive sampling yaitu penentuan sampel dengan pertimbangan kriteria tertentu, kriteria sampel tersebut adalah :

1. Bank Syariah yang telah menyampaikan laporan keuangan dan dipublikasikan oleh Bank Indonesia pada kurun waktu 2010-2014.

2. Bank Syariah yang telah menyampaikan laporan keuangan 
secara berturut-turut selama periode penelitian yaitu pada kurun waktu 2010-2014.

Sehingga jumlah sampel dalam penelitian ini ialah sebanyak 7 (tujuh) Bank Umum Syariah yang terdapat di Indonesia.

\section{Definisi Operasional}

1. Variabel Independen

a. Inflasi

Inflasi dihitung berdasarkan persentase kenaikan Indeks Harga Konsumen (IHK). Data Indeks Harga Konsumen dalam penelitian ini diperoleh dari Badan Pusat Statistik. Perhitungan tingkat Inflasi menurut Indeks Harga Konsumen diperoleh dengan rumus sebagai berikut:

$$
\mathrm{INF}_{t}=\frac{\mathrm{IHK}_{t}-\mathrm{IHK}_{t-1}}{\mathrm{IHK}_{\mathrm{t}-1}} \times 100 \%
$$

\section{Keterangan :}

$$
\begin{aligned}
& \text { IHK }_{\mathrm{t}} \text { : Indeks Harga Konsumen Periode Saat Ini } \\
& \text { IHK }_{\mathrm{t}-1} \text { : Indeks Harga Konsumen Periode Lalu }
\end{aligned}
$$

b. Tingkat Suku Bungka

Jumlah Uang Beredar yang digunakan dalam penelitian ini adalah Jumlah Uang Beredar dalam arti luas atau M2 yang diperoleh dari Statistik Indonesia pada Badan Pusat Statistik dan dihitung dalam satuan milyar rupiah per tahun periode Januari 2010 sampai dengan Desember 2014.

\section{c. Nilai Tukar}

Produk Domestik Bruto yang digunakan dalam penelitian ini adalah jumlah Produk Domestik Bruto atas dasar harga konstan yang diperoleh dari Badan Pusat Statistik dan dihitung dalam satuan milyar rupiah pertahun periode Januari 2010 sampai dengan Desember 2014.
2. Variabel Dependen

Variabel dependen dalam penelitian ini adalah Return On Asset (ROA), berdasarkan ketentuan yang ditetapkan oleh Bank Indonesia (BI) rumus untuk menghitung Return On Asset (ROA) adalah sebagai berikut:

\section{$\frac{\text { Laba Setelah Pajak }}{\text { Total Aset }} \times 100 \%$}

\section{Uji Instrumen}

1. Uji Asumsi Klasik

a. Normalitas

Uji Normalitas bertujuan untuk mengetahui apakah dalam suatu model regresi linier variabel terikat dan variabel bebas keduanya mempunyai distribusi normal atau tidak. Model regresi yang baik adalah memiliki distribusi data normal atau mendekati normal. Cara untuk melihat normalitas adalah dengan menggunakan uji JarqueBera. Jarque-Bera adalah uji statistik untuk mengetahui apakah data berdistribusi normal. Pengambilan keputusan uji normalitas dengan cara, yaitu jika nilai probabilitas JB lebih besar dari $\alpha$ 5\% (prob. J$\mathrm{B}>0,05)$, maka berdistribusi normal. Jika nilai probabilitas J-B lebih kecil dari a 5\% (prob. J-B < $0,05)$, maka berdistribusi tidak normal (Kusuma, 2012).

b. Autokorelasi

Autokorelasi merupakan korelasi antara satu variabel gangguan dengan variabel gangguan yang lain (Widarjono, 2009). Menurut Kusuma (2012) pengujian autokorelasi dapat dilakukan dengan menggunakan uji DurbinWatson, dimana pengambilan keputusan dapat dilakukan dengan membandingkan nilai uji D-W(d) dengan nilai tabel D-W (dL dan dU). 
c. Heteroskedastisitas

Heteroskedastisitas adalah kondisi dimana variabel gangguan (ei) mempunyai varian yang tidak konstan (Widarjono, 2009). Menurut Kusuma (2012) terdapat beberapa metode untuk mengidentifikasi terjadinya heteroskedastisitas pada analisis regresi menggunakan OLS, diantaranya:

1) Uji White

Uji ini menggunakan residual kuadrat sebagai variabel dependen dan variabel independennya terdiri atas variabel independen yang sudah ada ditambah dengan kuadrat variabel independen ditambah lagi dengan perkalian dua variabel independen. Pengambilan keputusan adalah sebagai berikut:

a) Probabilitas Chi-Square (pvalue) $>0,05 \quad(\alpha)$ tidak terjadi Heteroskedastisitas.

b) Probabilitas Chi-Square (pvalue $)<0,05 \quad(\alpha)$ terjadi Heteroskedastisitas.

2) Uji Breusch - Pagan - Godfrey (BPG)

Uji BPG merupakan uji yang memerlukan pengurutan dan penghilangan data. Pengambilan keputusan adalah sebagai berikut :

a) Probabilitas Chi-Square (pvalue) $>0,05 \quad(\alpha)$ tidak terjadi Heteroskedastisitas.

b) Probabilitas Chi-Square (pvalue $)<0,05 \quad(\alpha)$ terjadi Heteroskedastisitas.

d. Multikolinieritas

Adanya hubungan antara variabel independen dalam satu regresi disebut dengan multikolinearitas (Widarjono, 2009). Multikolinearitas merupakan salah satu masalah dalam analisis regresi OLS, yang berarti terdapat korelasi atau hubungan yang sangat tinggi di antara variabel independen. Multikolinearitas hanya tejadi pada regresi majemuk, karena melibatkan beberapa variabel independen sehingga tidak terjadi pada regresi sederhana (Kusuma, 2012).

Indikasi terjadinya multikolinearitas dapat ditunjukkan dari berbagai kondisi berikut (Widarjono, 2009):

1) Nilai R2tinggi $(>0,8)$ tetapi hanya sedikit variabel independen yang signifikan.

2) Koefisien korelasi yang tinggi (> 0,85) antar variabel independen.

3) Dengan melakukan regresi auxilliary, yaitu apabila nilai $\mathrm{F}$ hitung lebih besar dari nilai $\mathrm{F}$ kritis dengan tingkat signifikansi $\alpha$ dan derajat kebebasan tertentu.

\section{Teknik Analisis Data}

1. Analisis Regresi Berganda

Analisis regresi umumnya digunakan apabila tujuan analisis adalah prediksi hubungan sebab akibat antara variabel independen dan variabel dependen (Kuncoro, 2007). Dalam penelitian ini metode analisis data yang digunakan adalah regresi linier berganda dengan pengolahan data melalui Software SPSS 16.Dengan demikian model analisis dapat dinyatakan sebagai berikut:

$Y=\beta_{0}+\beta_{1} X_{1}+\beta_{2} X_{2}+\beta_{3} X_{3}+e$

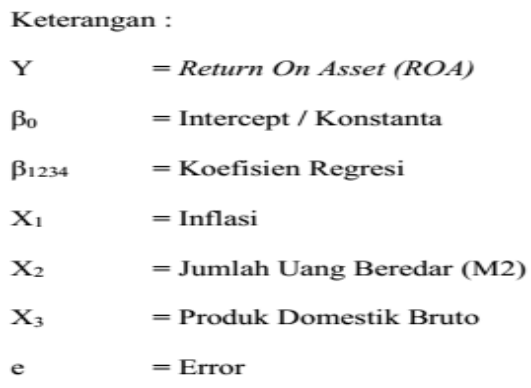


c. Heteroskedastisitas

Hasil Pengujian Uji White

\begin{tabular}{|l|r|l|r|}
\hline F-Statistic & 0.949806 & Prob. F(3,2) & 0.4491 \\
\hline Obs*R-squared & 3.934198 & Prob. Chi-Square(3) & 0.4150 \\
\hline Scaled explained SS & 6.994774 & Prob. Chi-Square(3) & 0.1362 \\
\hline
\end{tabular}

Dari hasil pemeriksaan

terhadap gejala heteroskedastisitas dengan menggunakan uji White, diketahui nilai Prob.Chi-Square pada Obs*RSquared lebih besar daripada $\alpha$ 5\%. Jadi, dalam kasus ini tidak ditemukannya gejala heteroskedastisitas.

Hasil Pengujian Uji Breusch-Pagan-Godfrey (BPG)

\begin{tabular}{|l|l|l|r|}
\hline F-Statistic & 0.623881 & Prob. F(3,2) & 0.6050 \\
\hline Obs*R-squared & 1.992826 & Prob. Chi-Square(3) & 0.5739 \\
\hline Scaled explained SS & 3.543128 & Prob. Chi-Square(3) & 0.3152 \\
\hline
\end{tabular}

Dari hasil pemeriksaan

terhadap gejala heteroskedastisitas dengan menggunakan uji BreuschPagan-Godfrey (BPG), diketahui nilai Prob.Chi-Square pada Obs*RSqured pada Obs*R-squared lebih besar daripada $\alpha 5 \%$. Jadi, dalam kasus ini tidak ditemukannya gejala heteroskedastisitas.

d. Multikolinieritas

Hasil Pengujian Uji Multikolinearitas

\begin{tabular}{|c|c|c|c|}
\hline & Inflasi & Jumlah Uang Beredar & PDB \\
\hline Inflasi & 1.000000 & 0.539398 & 0.532506 \\
\hline Jumlah Uang Beredar & 0.539398 & 1.000000 & 0.999756 \\
\hline PDB & 0.532506 & 0.999756 & 1.000000 \\
\hline
\end{tabular}

Dari hasil pengujian korelasi independen di atas terlihat adanya nilai korelasi (derajat keeratan) yang sangat tinggi yaitu lebih dari $90 \%$ (> 0.90) antar variabel independen. Jika variabel independen berkorelasi lebih dari $90 \%$ menunjukkan adanya gejala multikolinearitas. Meskipun data telah diperbaiki melalui transformasi data, namun data tetap menunjukkan adanya gejala multikolinearitas.

2. Hasil Uji Regresi Linier Berganda Hasil Pengujian Regresi Linier Berganda

Coefficients $^{\mathbf{a}}$

\begin{tabular}{|l|r|r|r|r|r|}
\hline & \multicolumn{2}{|c|}{$\begin{array}{c}\text { Unstandardized } \\
\text { Coefficients }\end{array}$} & $\begin{array}{c}\text { Standardized } \\
\text { Coefficients }\end{array}$ & & \multirow{2}{*}{} \\
\cline { 2 - 5 } Model & \multicolumn{1}{|c|}{$\mathrm{B}$} & \multicolumn{1}{|c|}{ Std. Error } & \multicolumn{1}{c|}{ Beta } & \multicolumn{1}{c|}{$\mathrm{t}$} & \multicolumn{1}{c}{ Sig. } \\
\hline 1 (Constant) & -.937 & .430 & & -2.178 & .037 \\
INFLASI & -.019 & .079 & -.049 & -.242 & .811 \\
M2 & $-2.224 \mathrm{E}-7$ & .000 & -17.375 & -2.249 & .032 \\
PDB & $2.184 \mathrm{E}-7$ & .000 & 17.148 & 2.231 & .033 \\
\hline
\end{tabular}

Dari tabel di atas dapat dirumuskan persamaan regresi berdasarkan tabel sebagai berikut :

ROA $=$ - 0,937 - 0,019 Inflasi - 2,224E7 Uang Beredar + 2,184E-7 PDB

Dari persamaan di atas dapat dijelaskan sebagai berikut:

a. Nilai koefisien konstanta sebesar 0,937. Hal ini mengindikasikan bahwa apabilai nilai Inflasi, Jumlah Uang Beredar dan Produk Domestik Bruto sama dengan 0 (nol), maka besarnya variabel Return On Asset sebesar -0,937.

b. Nilai koefisien Inflasi sebesar 0,019 . Hal ini berarti apabilai nilai Inflasi mengalami kenaikan sebesar 1 (satu) poin sementara variabel independen lainnya bersifat tetap, maka tingkat Return On Asset akan menurunsebesar 0,019 .

c. Nilai koefisien Jumlah Uang Beredar sebesar -2,224E-7. Hal ini berarti apabila nilai Jumlah Uang Beredar mengalami kenaikan sebesar 1 (satu) poin sementara variabel independen lainnya bersifat tetap, maka tingkat Return On Asset akan menurun sebesar 2,224E-7.

d. Nilai koefisien Produk Domestik Bruto sebesar 2,184E-7. Hal ini berarti apabila nilai Produk Domestik Bruto mengalami kenaikan sebesar 1 (satu) poin sementara variabel independen lainnya bersifat tetap, maka tingkat Return On Asset akan meningkat sebesar 2,184E-7.

3. Hasil Uji Parsial (Uji T)

Hasil Pengujian Uji Parsial (Uji-t)

Coefficients $^{\mathrm{a}}$

\begin{tabular}{|l|r|r|r|r|r|}
\hline \multirow{2}{*}{ Model } & \multicolumn{2}{|c|}{$\begin{array}{c}\text { Unstandardized } \\
\text { Coefficients }\end{array}$} & $\begin{array}{c}\text { Standardized } \\
\text { Coefficients }\end{array}$ & & \multirow{2}{*}{ Sig. } \\
\cline { 2 - 6 } & \multicolumn{1}{|c|}{$\mathrm{B}$} & Std. Error & \multicolumn{1}{c|}{ Beta } & \multicolumn{1}{c|}{$\mathrm{t}$} & \multicolumn{1}{c|}{ Sig. } \\
\hline (Constant) & -.937 & .430 & & -2.178 & .037 \\
INFLASI & -.019 & .079 & -.049 & -.242 & .811 \\
M2 & $-2.224 \mathrm{E}-7$ & .000 & -17.375 & -2.249 & .032 \\
PDB & $2.184 \mathrm{E}-7$ & .000 & 17.148 & 2.231 & .033 \\
\hline
\end{tabular}


a. Pengujian Hipotesis Pengaruh Inflasi terhadap Return On Asset (H1).

Berdasarkan tabel di atas dapat diketahui bahwa nilai $t$ hitung variabel Inflasi sebesar 0,242 dengan angka probabilitas signifikansi 0,811 . Hal tersebut menunjukkan bahwa angka probabilitas signifikansi variabel Inflasi lebih besar dari $0,05(0,811$ $>$ 0,05). Dapat disimpulkan bahwa H0 diterima dan Ha ditolak, yang berarti Inflasi tidak berpengaruh signifikan terhadap Return On asset.

b. Pengujian Hipotesis Pengaruh Jumlah Uang Beredar terhadap Return On Asset (H2).

Berdasarkan tabel di atas dapat diketahui bahwa nilai t hitung variabel Jumlah Uang Beredar sebesar -2,249 dengan angka probabilitas signifikansi 0,032 . Hal tersebut menunjukkan bahwa angka probabilitas signifikansi variabel Jumlah Uang Beredar lebih kecil dari $0,05(0,032<0,05)$. Dapat disimpulkan bahwa H0 ditolak dan Haditerima, yang berarti Jumlah Uang Beredar berpengaruh signifikan terhadap Return On Asset.

c. Pengujian Hipotesis Pengaruh Produk Domestik Bruto terhadap Return On Asset (H3).

Berdasarkan tabel di atas dapat diketahui bahwa nilai $\mathrm{t}$ hitung variabel Produk Domestik Bruto sebesar 2,231 dengan angka probabilitas signifikansi 0,033 . Hal tersebut menunjukkan bahwa angka probabilitas signifikansi variabel Produk Domestik Bruto lebih kecil dari $0,05(0,033<0,05)$. Dapat disimpulkan bahwa H0 ditolak dan Haditerima, yang berarti Produk Domestik Bruto berpengaruh signifikan terhadap Return On Asset.
4. Hasil Uji Simultan (Uji F)

Hasil Pengujian Uji Simultan (Uji F)

\begin{tabular}{|c|c|c|c|c|c|c|}
\hline \multicolumn{7}{|c|}{ ANOVA $^{b}$} \\
\hline \multicolumn{2}{|c|}{ Model } & $\begin{array}{l}\text { Sum of } \\
\text { Squares }\end{array}$ & $\mathrm{df}$ & $\begin{array}{l}\text { Mean } \\
\text { Square }\end{array}$ & $\mathrm{F}$ & Sig. \\
\hline 1 & Regression & .000 & 3 & .000 & 2.967 & $.047^{2}$ \\
\hline & Residual & .002 & 31 & .000 & & \\
\hline & Total & .002 & 34 & & & \\
\hline
\end{tabular}

Dari hasil uji simultan di atas, diketahui nilai $\mathrm{F}$ hitung adalah sebesar 2,967 dengan tingkat signifikansi 0,047 . Oleh karena probabilitas 0,047 lebih kecil dari 0,05 maka H0 ditolak dan Ha diterima, yang berarti Inflasi, Jumlah Uang Beredar dan Produk Domestik Bruto secara simultan berpengaruh signifikan terhadap Return On Asset Bank Syariah di Indonesia.

5. Hasil Uji Koefisien Determinasi Hasil Pengujian Uji Koefisien Determinasi $\left(\mathrm{R}^{2}\right)$

\begin{tabular}{|l|c|r|c|c|}
\hline & & & Model Summary \\
Model & $\mathrm{R}$ & R Square & $\begin{array}{c}\text { Adjusted R } \\
\text { Square }\end{array}$ & $\begin{array}{c}\text { Std. Error of the } \\
\text { Estimate }\end{array}$ \\
\hline 1 & $.472^{\mathrm{a}}$ & .223 & .148 & .0072196 \\
\hline
\end{tabular}
Dari hasil uji koefisien determinasi di atas, diketahui bahwa nilai Rsquared sebesar 0,223. Hal ini menunjukkan bahwa 22,3\% Return On Asset (ROA) dapat dijelaskan oleh variabel independen yaitu Inflasi, Jumlah Uang Beredar dan Produk Domestik Bruto. Sisanya sebesar $\quad 77,7 \% \quad(100 \%-22,3 \%)$ dijelaskan oleh variabel-variabel lain di luar penelitian.

\section{Pembahasan}

Berdasarkan hasil analisis diatas menunjukkan bahwa secara parsial variabel Jumlah Uang Beredar dan Produk Domestik Bruto terbukti berpengaruh signifikan terhadap Return On Asset (ROA) Bank Syariah di Indonesia. Sedangkan variabel Inflasi terbukti tidak ada pengaruh secara signifikan terhadap Return On Asset (ROA) Bank Syariah di Indonesia. Namun secara simultan variabel independen yang terdiri dari Inflasi, 
Jumlah Uang Beredar dan Produk Domestik Bruto terbukti mempunyai pengaruh yang signifikan terhadap Return On Asset (ROA) Bank Syariah di Indonesia periode 2010-2014.

Inflasi adalah kecenderungan dari harga-harga untuk naik secara umum dan terus-menerus dalam jangka waktu yang lama (Boediono, 1987). Berdasarkan hasil pengujian menunjukkan bahwa Inflasi tidak berpengaruh signifikan terhadap Return On Asset (ROA) Bank Syariah di Indonesia periode 2010-2014. Hal ini ditunjukkan dengan nilai probabilitas signifikansi pada uji-t sebesar 0,811 yang lebih besar dari a 5\% (0,811 > $0,05)$. Hasil penelitian ini sesuai dengan penelitian Saputra (2015) yang menyatakan bahwa Inflasi tidak berpengaruh signifikan terhadap Return On Asset (ROA) Bank Syariah di Indonesia. Hasil ini juga didukung oleh Anto (2012) yang menyatakan bahwa tingkat inflasi yang terjadi di Indonesia tidak berpengaruh dalam meningkatkan atau menurunkan profitabilitas bank syariah di Indonesia. Hasil ini juga diperkuat oleh penelitian Rosanna (2007) yang mengatakan bahwa pada saat inflasi tinggi maka masyarakat lebih percaya terhadap perbankan syariah dibandingkan dengan perbankan konvensional. Kepercayaan masyarakat tersebut juga dimungkinkan karena adanya pengalaman historis pada saaat terjadi krisis ekonomi tahun 1997, dimana pada masa tersebut tingkat inflasi di Indonesia sangan tinggi dan akhirnya mengakibatkan banyak bank konvensional yang mengalami kebangkrutan akibat menerapkan tingkat bunga yang terlalu tinggi untuk mengimbangi laju inflasi serta untuk menarik nasabah agar tetap menempatkan dananya sehingga mengakibatkan terjadinya negatif spread dan pada akhirnya bank tersebut tidak dapat mengembalikan dana masyarakat yang telah disimpan beserta bunganya.
Jumlah Uang Beredar (M2) adalah penjumlahan M1 dengan deposito berjangka dan saldo tabungan milik masyarakat pada bank (Boediono, 2008). Berdasarkan hasil pengujian menunjukkan bahwa Jumlah Uang Beredar berpengaruh negatif dan signifikan terhadap Return On Asset (ROA) Bank Syariah di Indonesia periode 2010-2014. Hal ini ditunjukkan dengan nilai probabilitas signifikansi pada uji-t sebesar 0,032 yang lebih kecil dari a 5\% (0,032<0,05). Hasil penelitian ini sesuai dengan penelitian Rahmiati (2010) yang menyatakan bahwa Jumlah Uang Beredar berpengaruh negatif dan signifikan terhadap Return On Asset (ROA) Bank Syariah di Indonesia. Meningkatnya Jumlah Uang Beredar di masyarakat akan diikuti juga dengan meningkatnya suku bunga yang diterapkan pemerintah sehingga mengakibatkan nasabah memindahkan dananya ke bank konvensional, untuk memperoleh pengembalian yang lebih tinggi. Naiknya suku bunga bank konvensional akan mempengaruhi kegiatan operasional bank syariah yaitu dalam hal pembiayaan dan penyaluran dana, bila hal tersebut terjadi maka pendapatan dan profit bank syariah akan menurun (Karim, 2006). Hal ini terbukti dimana pada saat Jumlah Uang Beredar mengalami kenaikan tertinggi selama periode pengamatan yaitu pada tahun 2014 yaitu sebesar Rp.4.173.327.000, rata-rata Return On Asset (ROA) perbankan syariah justru mengalami penurunan sebesar $66,7 \%$ pada tahun yang sama.

Produk Domestik Bruto adalah seluruh barang dan jasa yang dihasilkan seluruh warga masyarakat (termasuk warga negara asing) suatu negara dalam periode tertentu, biasanya dalam kurun waktu satu tahun (Soebagyo, 2013). Berdasarkan hasil pengujian menunjukkan bahwa Produk Domestik Bruto berpengaruh positif dan signifikan terhadap Return On Asset (ROA) Bank Syariah di Indonesia periode 2010-2014. 
Hal ini ditunjukkan dengan nilai probabilitas signifikansi pada uji-t sebesar 0,033yang lebih kecil dari $\alpha$ 5\% $(0,033<$ $0,05)$. Hasil penelitian ini sesuai dengan penelitian Sahara (2013) yang menyatakan bahwa Produk Domestik Bruto berpengaruh positif dan signifikan terhadap Return On Asset (ROA) Bank Syariah di Indonesia. Berpengaruhnya Produk Domestik Bruto terhadap Return On Asset (ROA) perbankan syariah menandakan meningkat dan menurunnya Produk Bomestik Bruto Indonesia sangat mempengaruhi nasabah dalam menyimpan dananya di bank. Meningkatnya Produk Domestik Bruto akan berpengaruh positif terhadap pendapatan konsumen sehingga akan meningkatkan pola saving terhadap perusahaan perbankan. Menurut Sukirno (2003) Produk Domestik Bruto dapat mempengaruhi profitabilitas bank, sesuai dengan teori Keynes bahwa besarnya tabungan bukan dipengaruhi oleh tingkat bunga, namun dipengaruhi oleh besar kecilnya tingkat pendapatan konsumen. Hal ini terbukti dimana pada tahun 2014 Produk Domestik Bruto mengalami penurunan sebesar $5,02 \%$ diikuti dengan penurunan rata-rata Return On Asset (ROA) perbankan syariah di Indonesia. Dan di tahun 2012, Produk Domestik Bruto mengalami kenaikan sebesar $6.03 \%$ diikuti juga dengan kenaikan rata-rata Return On Asset (ROA) perbankan syariah di Indonesia pada tahun yang sama.

\section{KESIMPULAN DAN SARAN}

\section{Kesimpulan}

1. Inflasi secara parsial tidak berpengaruh signifikan terhadap Return On Asset (ROA) Bank Syariah di Indonesia periode 2010-2014.

2. Jumlah Uang Beredar secara parsial berpengaruh negatif dan signifikan terhadap Return On Asset (ROA) Bank
Syariah di Indonesia periode 20102014.

3. Produk Domestik Bruto secara parsial berpengaruh positif dan signifikan terhadap Return On Asset (ROA) Bank Syariah di Indonesia periode 20102014.

4. Secara simultan Inflasi, Jumlah Uang Beredar dan Produk Domestik Bruto berpengaruh signifikan terhadap Return On Asset (ROA) Bank Syariah di Indonesia periode 2010-2014.

\section{Saran}

1. Untuk Peneliti selanjutnya diharapakan dapat menambah variabel independen yang lebih banyak seperti nilai tukar rupiah, karena Bank Syariah juga menjalankan aktivitas riil yang berkaitan dengan ekspor dan impor, serta variabel makroekonomi lainnya yang sesuai dengan topik penelitian.

2. Untuk pihak perbankan syariah diharapkan bisa mengantisipasi risiko operasional bank syariah yang berkaitan dengan Inflasi, Jumlah Uang Beredar dan Produk Domestik Bruto.

3. Untuk peneliti selanjutnya diharapkan untuk meneliti mengenai perilaku konsumen perbankan syariah di Indonesia, Karena yang menjadi nasabah bank syariah bukan hanya nasabah muslim melainkan terdiri dari berbagai latar belakang.

\section{DAFTAR PUSTAKA}

Alim, Syahirul. (2014). Analisis Pengaruh Inflasi dan BI Rate Terhadap Return On Asset (ROA) Bank Syariah di Indonesia. Jurnal Ilmu Manajemen UIN Maliki Malang (Januari), hal 1-21. 
Anto., Wibowo, dan M. Ghafur. (2012). Faktor-Faktor Penentu Tingkat Profitabilitas Bank Umum Syariah di Indonesia. Jurnal Ekonomi Islam La Riba (Januari), hal 14-16.

Boediono. (2008). Ekonomi Moneter. Yogyakarta: BPFE.

Dwijayanthy, Febrina. (2009). Analisis Pengaruh Inflasi, BI Rate dan Nilai Tukar Mata Uang Terhadap Profitabilitas Bank Periode 20032007. Jurnal Ilmu Manajemen Universitas Paramadina Jakarta (Maret) hal 1-12.

Husnan, Suad. (1992). Bank dan Lembaga Keuangan Lain. Jakarta: Salemba Empat.

Julianti, Friska. (2013). Analisis Pegaruh Inflasi, Nilai Tukar dan BI Rate terhadap Tabungan Mudharabah pada Perbankan Syariah. Skripsi. Jakarta: Fakultas Ekonomi dan Bisnis UIN Syarif Hidayatullah Jakarta.

Karim, Adiwarman A. (2006). Bank Islam Analisis Fiqih dan Keuangan. Jakarta: PT. Raja Grafindo Persada.

Kuncoro, Mudrajat. (2001). Metode Kuantitatif: Teori dan Aplikasi Untuk Bisnis dan Ekonomi. Yogyakarta: UPP-AMP YKPN.

Kusuma, Desta Rizky., dan Deny Ismanto. (2012). Modul Praktikum Eviews. Yogyakarta: Pusat Pengembangan Manajemen Fakultas Ekonomi

Univeritas Ahmad Dahlan.

Muhammad. (2005). Manajemen Pembiayaan Bank Syariah. Yogyakarta: UPP AMP YKPN.

Oktavia, Linda D. (2009). Pengaruh Suku Bunga SBI, Nilai Tukar Rupiah dan Inflasi Terhadap Kinerja Keuangan Perusahaan Sebelum dan
Sesudah Privatisasi (Studi Kasus Pada PT. Telekomunikasi Indonesia, Tbk). Jurnal Bisnis dan Manajemen (Januari), hal 1-10.

Rahmiati, Tetty Sari. (2010). Pengaruh Kurs, Tingkat Inflasi, Tingkat Bunga dan Jumlah Uang Beredar Terhadap Kemampulabaan Bank Umum Syariah di Indonesia Periode Tahun 2006-2009. Jurnal Ilmu Manajemen Universitas Bakrie (Maret), Hal 1-9.

Rivai, Veithal, dkk. (2007). Bank and Financial Institution Management Conventional \& Sharia System. Jakarta: Erlangga.

Rosanna, Rizky Dahlia. (2007). Pengaruh Inflasi, Nilai Tukar dan Suku Bunga SBI Terhadap Profitabilitas Perbankan Syariah di Indonesia Tahun 2002-2006. Tesis. Yogyakarta: Universitas Islam Yogyakarta.

Sahara, Ayu Yunita. (2013). Analisis Pengaruh Inflasi, Suku Bunga BI dan Produk Domestik Bruto terhadap Return On Asset (ROA) Bank Syariah di Indonesia. Jurnal Ilmu Manajemen (Januari) hal 1-6. Universitas Negeri Surabaya.

Saputra, Anas Tinton. (2015). Pengaruh Variabel Makroekonomi Terhadap Profitabilitas Perbankan Syariah di Indonesia. Jurnal Ekonomi dan Bisnis Universitas Muhammadiyah Surakarta (Juli), hal 1-17.

Sekaran, Uma. (2006). Metode Penelitian Untuk Bisnis. Jakarta: Salemba Empat.

Setiadi, Pompong B. (2010). Analisis Hubungan Spread of Interest Rate, Free Based Income dan Loan to Deposit Ratio dengan ROA pada Perbankan di Jawa Timur. Jurnal 
Ekonomi dan Manajemen (Maret), hal 10-20.

Soebagiyo, Daryono. (2013).

Perekonomian Indonesia. Surakarta:

Fakultas Ekonomi Universitas

Muhammadiyah Yogyakarta.

Suardani, Putri. (2009). Pengaruh

Beberapa Variabel Ekonomi Makro

Terhadap Kinerja Keuangan dan

Return Saham Perusahaan Pada

Industri Manufaktur di Pasar Modal

Indonesia. Jurnal Bisnis dan

Manajemen (Maret), hal 2-8.

Sugiyono. (2007). Statistika Untuk

Penelitian. Bandung: Alfabeta.

Sukirno, Sadono. (2003). Teori Pengantar

Ekonomi Makro. Jakarta: PT. Raja

Grafindo Persada.

Widarjono, Agus. (2009). Ekonometrika

Pengantar dan Aplikasinya.

Yogyakarta: Ekonisia. 